Issues in Preventive Psychiatry 
This publication is supported in part by the Theodor Theohari Cozzika Foundation 


\section{Issues in Preventive Psychiatry}

Editors George N. Christodoulou, Athens Dusica Lecic-Tosevski, Belgrade

Vassilis P. Kontaxakis, Athens

Preface by Norman Sartorius, Geneva

1 figure and 13 tables, 1999

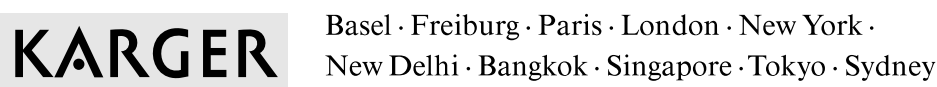




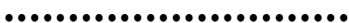

\section{George N. Christodoulou, MD}

Section of Preventive Psychiatry

World Psychiatric Association

Eginition Hospital

Athens (Greece)

Library of Congress Cataloging-in-Publication Data

Issues in preventive psychiatry / editors, George N. Christodoulou, Dusica Lecic-Tosevski,

Vassilis P. Kontaxakis.

Includes bibliographical references and indexes.

1. Mental illness - Prevention Congresses. I. Christodoulou, G.N. II. Lecic-Tosevski, Dusica.

III. Kontaxakis, V.P. (Vassilis P.)

[DNLM: 1. Mental Disorders - prevention \& control Congresses. WM 140 I86 1999]

RA790.A2I86 1999 616.89-dc21

ISBN 3-8055-6912-2 (hardcover)

Bibliographic Indices. This publication is listed in bibliographic services, including Current Contents ${ }^{\circledR}$ and Index Medicus.

Drug Dosage. The authors and the publisher have exerted every effort to ensure that drug selection and dosage set forth in this text are in accord with current recommendations and practice at the time of publication. However, in view of ongoing research, changes in government regulations, and the constant flow of information relating to drug therapy and drug reactions, the reader is urged to check the package insert for each drug for any change in indications and dosage and for added warnings and precautions. This is particularly important when the recommended agent is a new and/or infrequently employed drug.

All rights reserved. No part of this publication may be translated into other languages, reproduced or utilized in any form or by any means electronic or mechanical, including photocopying, recording, microcopying, or by any information storage and retrieval system, without permission in writing from the publisher.

(c) Copyright 1999 by S. Karger AG, P.O. Box, CH-4009 Basel (Switzerland)

www.karger.com

Printed in Switzerland on acid-free paper by Reinhardt Druck, Basel

ISBN 3-8055-6912-2 


\section{Contents}

VII Preface

Sartorius, N. (Geneva)

\section{Introduction}

Christodoulou, G.N. (Athens); Lecic-Tosevski, D. (Belgrade);

Kontaxakis, V.P. (Athens)

1 The Relevance of Comprehensive Clinical Diagnosis to Prevention and Health Promotion

Mezzich, J.E. (New York, N.Y.); Schmolke, M.M. (Munich)

7 The Role of Genetics in the Prevention of Psychiatric Disorders Papadimitriou, G.N.; Dikeos, D.G. (Athens)

17 Prevention of Mental Disorders in Primary Care Mavreas, V.G. (Athens)

30 Violence and Parenting Education Fink, P.J. (Bala Cynwyd, Pa.)

39 Prevention of Mental Disorders in England Jenkins, R. (London)

47 Preventive Aspects of the Mental Health Care System Reform in Greece

Madianos, M.G. (Athens)

55 Psychosocial Approaches to the Prevention of Depression Newton, J. (London)

66 Suicide Prevention Strategies: The Role of Health Care Workers Rihmer, Z.; Füredi, J. (Budapest) 
79 Long-Term Impact of Lithium Prophylaxis on the Course of Bipolar Disorder

Maj, M. (Naples)

83 From the Leros Asylum to Sheltered Housing in the Community Christodoulou, G.N.; Kontaxakis, V.P.; Havaki-Kontaxaki, B.J.;

Scoumbourdis, T. (Athens)

90 Mortality of Schizophrenic Inpatients in Athens Kontaxakis, V.P.; Havaki-Kontaxaki, B.J.; Christodoulou, G.N. (Athens)

95 Posttraumatic Stress Disorder in Refugees and Its Relationship with Personality Dimensions

Lecic-Tosevski, D.; Draganic, S.; Jovic, V.; Ilic, Z.; Drakulic, B.; Bokonjic, S. (Belgrade)

103 Educational Aspects in the Preventive Work against Torture Kastrup, M.; Genefke, I. (Copenhagen)

112 Epistemology and Prevention of Mental Health Papart, J.-P.; Chastonay, P.; Heggerickx, I. (Geneva)

126 Research Methods in the Field of Psychiatric Prevention Rössler, W.; Eichenberger, A. (Zürich)

134 Prevention of Deontological Mistakes: The Role of Ethical Codes Okasha, A. (Cairo)

143 Author Index

144 Subject Index 


\section{........................... \\ Preface}

Several years ago, the World Health Assembly - the supreme decisionmaking body for international health - received a report from the DirectorGeneral of the World Health Organization outlining possibilities for the primary prevention of mental and neurological disorders. The report gave a systematic description of activities that could be undertaken by the health sector and by other social sectors to prevent the appearance of these disorders. It estimated that, in many countries, as much as one third to one half of all mental and neurological disorders could be averted by primary prevention measures. It provided suggestions about the types of service and staff that would have to be involved, and demonstrated that most preventive activities in the field of mental health could be carried out even in very poor countries.

The assembly received the report with much interest and adopted a resolution urging governments worldwide to implement the activities outlined in the report. A few years later a follow-up report showed that some progress had been made but that, on the whole, primary prevention of mental and neurological disorders remained neglected in most settings.

The reasons for the neglect of prevention of psychiatric disorders are probably many: the most important among them are likely to be the unawareness of the availability of effective methods of prevention and the underestimation of the magnitude of mental health problems.

The book edited by George Christodoulou, Dusica Lecic-Tosevski and Vassilis Kontaxakis aims to make a contribution to the effort of correcting the neglect of prevention in psychiatry by presenting methods of prevention and their usefulness. It comes at a good time - shortly after a series of documents produced by the World Bank and others demonstrating the huge 
human and economic losses caused by mental illness. It also comes in an atmosphere of increasing conviction that action against psychiatric illness is urgent, that it can be effective and that it would be welcome by patients, their families and the society.

Its orientation makes it likely that this book will facilitate the implementation of prevention programs. Should this prove to be so its authors and editors would get the greatest reward that anyone could hope for - the awareness that their work has led to the improvement of the quality and quantity of life for many people and the society as a whole. I sincerely hope that they will receive this reward which their work amply deserves.

\section{Norman Sartorius}

President of the World Psychiatric Association 


\section{Introduction}

Despite the dictum of conventional wisdom that prevention is better than treatment, it is not clear which specific preventive interventions are indicated in each situation and to what extent these interventions are realistic and effective. This has created public scepticism towards preventive efforts. Another reason that accounts for the marginalization of prevention is associated with the lack of immediate gratification. Preventive interventions are usually indirect, nonpersonal, exercised by a variety of workers and often outside the mental health sector altogether.

Yet, limiting our efforts solely to treatment is like seeing the tree and missing the forest. Mental health workers should learn to see both, i.e. have a microscopic vista for individual cases and a macroscopic one to serve primary prevention.

In order to achieve this scope, collaboration with other mental health professionals but also with people only indirectly involved with mental health (teachers, the clergy, administrators, the police, journalists and practically every sector of the community) is essential. Psychiatric prevention is multifactorial and as such it needs a multidisciplinary and multidimensional approach in which the psychiatrist should be actively involved, usually exercising not overt but covert leadership.

A nonill person is not necessarily healthy. In keeping with the very old but also very relevant WHO definition of health ('health is a state of complete physical, mental and social well-being and not merely the absence of disease or infirmity') absence of illness is not enough. The ' $\varepsilon v$ ć $\chi \varepsilon 1 v$ ' (well-being) of the Ancient Greeks is additionally needed. Promotion of positive mental health is the arm by which well-being (a concept closely related to quality of life) can be reached. 
This book, published under the auspices of the World Psychiatric Association, contains selected papers from the Symposium of the WPA Section on Preventive Psychiatry held during the course of the 10th World Congress of Psychiatry, as well as invited papers by mental health workers in the field of psychiatric prevention. It is a follow-up to Aspects of Preventive Psychiatry (Karger, Basel, 1981) and Topics in Preventive Psychiatry (Karger, Basel, 1994) edited by the same team of editors.

We hope that this series of books will contribute to the promotion and dissemination of the principles of preventive psychiatry and also help in bringing preventive psychiatry closer to the professional public.

George N. Christodoulou

Dusica Lecic-Tosevski

Vassilis P. Kontaxakis

Introduction 